\title{
On Self-cognition (svasamvedana) in the Tattvasamgraha
}

\section{Akira Suganuma}

Śantarakșita quotes many views insisting upon the realistic existence of the external object and points out their absurdity in Bahirarthapari $k s \underline{a}$ or 'the examination of the external object', Tattvasamgraha. It seems that the arguments are mainly divided into two classes: one is on the atom (paramānuu) theory and the other is on the cognition (vijñāna) theory. Of these, I will treat here with the latter subject, especially, svasamvedana or 'self-cognition' of cognition, which forms one of the most important characteristics of the vijñana-system in this chapter of Tattvasamgraha. I suppose that we are able to understand the meaning of 'svasamvedana." through seeing the realistic assertion of Kumārila and Śantarakșita's refutation to it. In Tattvasamgraha, there are quoted a lots of verses from Śñnavāda and Nirālambanavāda, 'Slokavãrttika of Kumārila. In this Bahirarthapari kșa also mainly there quoted a few verses from Sínyavāda and criticized thoroughly by Śantarakșita.

I treated that the most basic standpoint found in this Bahirarthapariks $\bar{a}$ belonged to one of vijñannavādas. Vijñanna held by him is that which is endless and impure for persons who have not realized the truth yet, but pure for those who have cut off their obstacles. Besides, it is one which all beings depend upon, and which is destroyed at every moment. The triple world is only such vijñāna. Then, why is the triple world mere vijñāna?

(1) As to the meaning of Śūnyavāda itself, see Yamazaki, T.; "On 'Śūnyavāda' Quoted in Ślokavārttika” (Journal of Indian \& Buddhist Studies. Vol. 5. No. 2.)

(2) Cf. My "The Examination of the External Object in the Tattvasamgraha" (Journal of Indian \& Buddhist Studies. Vol. 10, No. 2). 
On Self-cognition (Svasamvedana) in the Tattvasamgraha(A. Suganuma)

It is because nothing exists, Śantarakșita says, except vijñāna which is 'self-cogniser'. He does not admit the realistic existence of the external objects at all. If the external object is recognised, according to him, it may be recognised either by the formless cognition (nirākāravijñāna), or by the cognition having a similar form (sākāravijñāna), or the cognition endowed with a different form from its objects (anyākāravijñāna). But he accepts neither the nirākāravijñannavāda, nor the sākaravijñānavāda, nor the

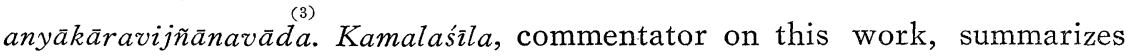
these into the following argument:

Every cognition is devoid of both 'the cognised' and 'the cogniser'. Because it is cognition.

Just like the cognition of the reflected image.

Thus, for Säntarakșita, cognition (jñanna) is fundamentally devoid of the cognised (grāhya) and the cogniser (grāhaka). That is to say, it has only nature of 'cognition'. Consequently the concept of 'svasamvedana', comes to have very important meaning in his vijñāna-system. At first Śantarakșita formulates a general difinition of svasamvedana as follows: Cognition (vijñāna, rnam-śes) is produced as differentiated from all the unconscious natures (jaḍarūpa, bems-pohi ran-bshin), when it is produced; it is this fact of its no-unconscious (ajada, bems-min) that constitutes its self-cognition (ätmasamvitti, bdag-ñid-śes-pa). Briefly speaking, cognition is difined as 'the no-unconscious' (ajada), not as the unconscious (jada), only because the cognition is 'self-cognisability', in the concrete, 'self-revelation' (ātmaprakāśa). Śāntarakșita explains it more concretly. A cognition does not depend upon any other cogniser (anyad-

( 3 ) Cf. My "Theory of Knowledge (jñāna) in the Tattvasamgraha". (Journal of Religious Studies. Vol. XXXV-3)

(4) Tattvasamgrahapañjikā, p. 550. yad yaj jñānaṃ tat tat grāhyagrāhakadvayarahitạ̣, jñānatvāt, pratibimbajñānavat.

(5) Ātmasaṃvedana, ātmasaṃvitti, ātmasaṃvid, svasaṃvedana, svasaṃvitti, svasamvedanā and svasamvit are strictly synonymous in the Bahirarthaparīkșā.

(6) Tattvasamgraha. 2000. 
(70) On Self-cognition (Svasamvedana) in the Tattvasamgraha(A. Suganuma) vedaka, ses-byed gshan) for cognition of its own form; and yet this all is not uncognised; this is what is meant by 'self-cognition' (svasamvid, ran-rig-pa). According to him, cognition is the illumination of its own by its nature. In order to illuminate itself, cognition never need any other things than itself.

It is to this point that Kumārila, Mimañmsaka, objects. He says: while it is operating towards the recognising of an object (arthasamvitti, donrtogs), a cognition (jñāna, śes-pa) does not touch itself. Hence, even though it is illuminative (prakāśatve'pi, gsal-byed-ñid yin-pas), it depends upon something else (anyat pratīkșate, gshan-la bltos-pa) for its own apprehension (bodhāya, rtogs-phyir). Even though a cognition is of illuminative nature, it does not illuminate itself. It is because, when it is engaged in one thing, it cannot operate over another thing, without abondoing the former. In other words, cognition cannot recognise itself, when it is engaged in the act of recognising an object. And when a cognition comes into existence, it recognises some object necessarily. Therefore cognition never cognise itself.

Santarakșita criticizes to this insistence of Kumārila in 2017-2020 verses. It is the cognition of the object (arthasya samvittih, don-la rnampar-rig-p̣a) that is called 'cognition' (jñanna, śes-pa). Then, when it forms its own essence, how could there be any other function (vyāpāra, bya-ba) over it? The cognition of an object (arthasamvitti) is of the nature of cognition. They are not distinguishable from each other. Kamalaśila explains that it is the cognition itself which is spoken of by such synonyms (paryāya) as vitti (rig-pa), upalabdhi (dmigs-pa), arthapratīti (don rnam-par-rig-pa) and vijñapti. As cognition of an object is not distinguishable from the cognition, no other cognitive act is needed for cognising of the object. These are formulated into following argument by Kamalasizla:

Every cognition does not depend upon the operation of anything else

(7) TS. 2012. (8) TS. 2013; Śūnyavāda, Ślokavārttika. 184.

(9) TS. 2017. (10) Vijñapti is not in Tib. 
for its own cogniton.

Because it is cognition.

Just like the final cognition of the series.

It is very important that there are two examples of the same reason (hetu), "because it is cognition" (jñānatvāt) to two propositions (pratijñã). That is, one is "every cognition is devoid of both the cognised and the cogniser" and the other is "every cognition does not depend upon the operation of anything else for its own cognition".

But Kumārila does not admit Śāntarakșita's maintenance. The illuminative character (prakāśatva, gsal-ba-ñid) of cognition may be regarded as consisting in its being apprehension of an object (arthānubhavātmaka, don bdag-ñid ñams-myon்). But as there is no apprehension of itself (ātmānubhava, bdag-ñid ñams-myon்), the cognition cannot be regarded as illuminating itself. As in the case of the eye, even though it is illuminative (sati prakāśatve'pi), yet it has its illuminativeness restricted to colour (rūpa), so it would be in the case of the cognition also.

Santarakșita's answer to this is as follows: The eye is regarded as illuminative (prakāśa, gsal-byed), not because it is its apprehension, but because it causes to happen the cognition (vijñāna, rnam-śes) of colour. Then what similarity (upamã, mtshuns) can the eye have to the cognition? Thus Kumarila's assertion consisting in similarity of the eye is pointed out its absurdity. But he assert further that the illuminativeness (prakāsatva) of cognition operates upon the external object (bāhyārtha), and not upon cognition itself, because of want of the capacity (śaktyabhāvāât). This assertion is criticised also by $\hat{S}_{a}$ ntarakșita. The essential nature of an object is 'apprehension' (anubhava, nams-myon). It is not distinguishable

(11) TSP. p. 566. yaj jñānam tad ātmabodhạ̣ praty anapekșitānyavyāpāram, jñānatvāt, antyajñānavat.

(12) TS. 2014-5: Śūnyavāda 185-6, 2015 and the former part of 2016 verse are not found in Peking Ed., tibetan version.

(13) TS. 2029.

(14) TS. 2016; Śūnyavāda. 187. 
(72) On Self-cognition (Svasamvedana) in the Tattvasamgraha(A. Suganuma)

from cognition. Otherwise the cognition cannot operate upon it. If the object is distinguishable from the cognition, it cannot be apprehended at all. As it does not differ from it, the cognition apprehends itself. Hence it is quite clear that Kumärila's wrong assertion comes from his standpoint which distinguishes the cognition from the apprehension of its object.

According to Śantarakșita, self-cognition (svasamvedana) is the essential nature of cognition (jñāna). Concretely speaking, it does not depenp upon something else for its own cognition. Besides, fundamentally it is devoid of both the cognised (grāhya) and the cogniser (grāhaka). So he concludes that primarily (mukhyatas, gtso-bor) cognition does not apprehend an object at all, because it abides within its own self (svasvabhāvasthiti, ran்-gi ran்-bshin-la-gnas-pa), and because there is absence of the imprint of the objective forms. This is made clear by Kamalasizla. He says: "When cognition is said to be self-cognition (ātmasamvedana), it is not regarded as the cognised (grāhya) and the cogniser (grāhaka). It is meant that it shines itself by itself-by its nature". Then, why is cognition. not regarded as the cognised and the cogniser? There can be no self-cognition (svasamvitti, ran-gi rig-pa) of the cognition in the sense that it is the action and the active agency (kriyākāraka, bya dan byed-pa), because one and the same thing which is impartite in form (anamśarūpa, cha-med-ran்-bshin) cannot have three characters (trairūpya, gsum-gyi ran்bshin). Three characters, in this case, are of the cognised (vedya), the cogniser (vedaka) and the cognition (vitti). One and impartite cognition cannot have such three characters at the same time. Consequently we can understand that his 'self-cognition' (svasamvedana) differs from one of the so-called ' theory that cognition has three characters'. It is never possible for him that cognition has such characters as the cognised, the cogniser and the cognition. The cognition is only of undivided character.

This presentation of three portions of cognition, vedya, vedaka and

(15) TS. 2034. (16) 'Grāhya' is left out in text, but gzun-ba in Tib.

(17) TSP. p. $559 . \quad$ (18) TS. 2001. 
On Self-cognition (Svasamvedana) in the Tattvasaṃgraha(A. Suganuma)

vitti, coincides with that of the Mãdhyamakaśāstra; for example, gantavya, gantṛ and gamaṇa in the Gatāgataparīkșā, drașțavya, drașț̣ and darśana in the Caksurādindriyaparīkșa, and karman, kartṛ and karaṇa in, the Karmakārakaparīkșa. These are represented also by Dignāga as prameya, pramātṛ and pramāṇa. Săntarakșita never admit the realistic existence of these characters, but regards cognition as the undivided. Therefore "self-cognition' asserted by him is different from that in 'the theory that cognition has three divisions' which have held by the traditional vijñannavãdin in China and Japan. Consequently, even though the usage 'self-cognition' (svasamvedana, ătmasamvedana, etc.) was used in this work, it is quite impossible to conclude that Śantarakșita's vijñānavāda stands on such 'theory that cognition has three divisions'. In other words, 'self-cognition' (svasamvedana) is not one of these three divisions of cognition in Saantarakșita's vijñāna system. His 'self-cognition' represents to be the unity of the cognition. And his vijñannavāda seems to stand on this unity of the cognition.

Thus in Śantarakșita's vijñāna-system, cognition is one which is devoid of the cognised and the cogniser, which is neither having form, nor formless, and which is one and impartite. Cognition, in actuality, is apprehending the non-objective form (abhūta-ākāra, yan்-dag-min rnampa), only through falsefood (vibhrama, ḩkhrul-pa), but in reality it does not apprehend it at all, for the simple reason that it has no object (nirvișaya, yul-med-pa). It seems that there exists even 'śunyatäic' tendancy in his vijñanna-theory. This fact is made clear by Kamalaśila quoting from Prajñä-păramita: "Cognition is of śunyatā as a nature of cognition, basing on sūnyatā of characteristic".

(19) Cf. Dr. Yamaguchi, S. : Bukkyo ni okeru U to Mu tono Tairon. Kyoto, 1941. p. $354 . \quad$ (20) TS. 2045.

(21) Dr. Kanaoka, S. used the usage "Śūnyatāic vijñāna" concerning Śāntideva's vijñāna theory ("Śāntideva's attitude towards vijñāna Theory”. Journal of Indian \& Buddhist Studies Vol. 10, No. 2)

(22) TSP. p. 580. vijñānam vijñānasvabhāvena śūnyam lakṣaṇaśūnyam upādāya. 